\title{
Harmonia axyridis (Coleoptera: Coccinellidae) as a host of the parasitic fungus Hesperomyces virescens (Ascomycota: Laboulbeniales, Laboulbeniaceae): A case report and short review
}

\author{
Piotr CERYNGIER ${ }^{1}$ and KAMILA TWARDOWSKA ${ }^{2}$ \\ ${ }^{1}$ Faculty of Biology and Environmental Sciences, Cardinal Stefan Wyszynski University, Wóycickiego 1/3, 01-938 Warsaw, Poland; \\ e-mail: p.ceryngier@uksw.edu.pl \\ ${ }^{2}$ Department of Phytopathology and Entomology, University of Warmia and Mazury in Olsztyn, Prawochenskiego 17, 10-721 \\ Olsztyn, Poland; e-mail: kamila.twardowska@wp.pl
}

\begin{abstract}
Key words. Ascomycota, Laboulbeniales, Hesperomyces virescens, Coleoptera, Coccinellidae, Harmonia axyridis, host-parasite association, novel host, range shift, host suitability, Acari, Podapolipidae, Coccipolipus hippodamiae, Nematoda, Allantonematidae, Parasitylenchus
\end{abstract}

\begin{abstract}
Hesperomyces virescens is an ectoparasite of some Coccinellidae, which until the mid-1990s was relatively rarely only reported from warm regions in various parts of the world. Analysis of the host and distribution data of $H$. virescens recorded in the Western Palaearctic and North America reveals several trends in the occurrence and abundance of H. virescens: (1) it has recently been much more frequently recorded, (2) most of the recent records are for more northerly (colder) localities than the early records and (3) the recent records are mostly of a novel host, the invasive harlequin ladybird (Harmonia axyridis). While in North America $H$. virescens is almost exclusively found on $H$. axyridis, all European records of this association are very recent and still less numerous than records of Adalia bipunctata as a host. However, based on a relatively few published cases of the $H$. axyridis- $H$. virescens association in Europe and the case described in this paper, it is clear that the harlequin ladybird is currently the main host of this parasite. These changes in the abundance and geographical distribution of $H$. virescens are probably linked to some features of $H$. axyridis, such as its abundance, multivoltinism with overlapping generations, high level of promiscuity and overwintering in mass aggregations. The occurrence of these features in one species may make it especially suitable for $H$. virescens and other parasites that require close contact of host individuals for efficient transmission. Indeed, some of the data indicate that parasites other than H. virescens, like the podapolipid mite Coccipolipus hippodamiae and allantonematid nematodes of the genus Parasitylenchus may also heavily parasitize $H$. axyridis. We hypothesize that the acquisition of $H$. axyridis as a host by $H$. virescens, $C$. hippodamiae and Parasitylenchus spp. may have further consequences for the abundance and distribution of these parasites, including the expansion of their ranges to other continents colonized by invasive populations of this ladybird and areas in Asia where $H$. axyridis is native.
\end{abstract}

\section{INTRODUCTION}

Fungi of the order Laboulbeniales are obligate ectoparasites of insects and other arthropods, but beetles (Coleoptera) are their most common hosts (Weir \& Hammond, 1997; Majewski, 2008). Compact thalli of Laboulbeniales attach to the cuticle of the host by a melanized terminal part of the basal cell called the foot. Thalli may be present over the entire surface of the integument of its host. Some species, however, occur only on specific parts of the body of their host. Laboulbeniales are relatively benign parasites that do not kill their hosts and rarely have an adverse effect on them (Tavares, 1979; Kaur \& Mukerji, 2006; Majewski, 2008).

Ladybird beetles (Coccinellidae) are the hosts of four species of the laboulbenialean genus Hesperomyces, with $H$. virescens Thaxter the most frequently recorded (Ceryngier et al., 2012). H. virescens is recorded infecting a wide array of ladybird hosts in many parts of the world, including North and South America, the Caribbean, Borneo, Melanesia, Japan, Near East, North Africa and Europe (Thaxter, 1931; Santamaria et al., 1991; Ceryngier et al., 2012).
One of the reported hosts of $H$. virescens is the harlequin ladybird, Harmonia axyridis (Pallas), an invasive species of Asiatic origin that from the late 1980s onwards rapidly expanded its range, at the beginning in the United States and currently in North and South America, Europe and Africa (Brown et al., 2011). The association between $H$. axyridis and $H$. virescens was first reported in Ohio (USA) in 2002 (Garcés \& Williams, 2004) and subsequently at many localities in eastern and central United States, with the percentage parasitization often reaching 70-100\% (Riddick \& Schaefer, 2005; Harwood et al., 2006a, b; Riddick, 2006, 2010; Nalepa \& Weir, 2007; Riddick \& Cottrell, 2010).

In the winter of 2006/2007, H. virescens was recorded for the first time on $H$. axyridis in Europe at an hibernation site of this beetle at Meise near Brussels (Belgium). At that time one out of 203 individuals of $H$. axyridis (about $0.5 \%$ ) was found to bear $H$. virescens thalli but four years later (winter 2010/2011), at the same site, $96.5 \%$ of the overwintering $H$. axyridis were infected (De Kesel, 2011). There are now other European records of $H$. axyridis infected with $H$. virescens from the Nether- 


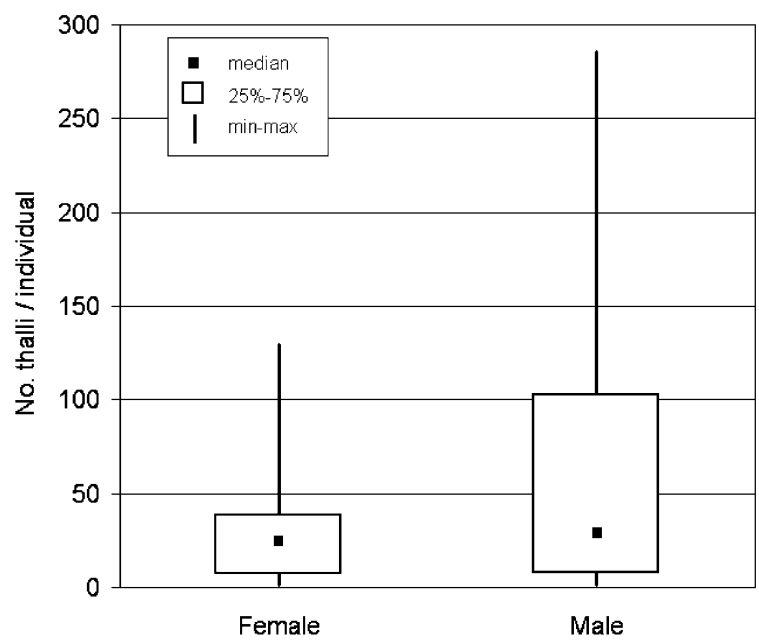

Fig. 1. Number of Hesperomyces virescens thalli on male and female Harmonia axyridis hosts.

lands, Germany and several Belgian localities (Steenberg \& Harding, 2010; De Kesel, 2011; Haelewaters \& De Kesel, 2011; Haelewaters et al., 2012). So far, this fungus is not reported attacking $H$. axyridis within its native (Asiatic) range, although it is reported infecting Coccinula crotchi (Lewis) and C. sinensis (Weise) in the eastern part of its range (Japan) (Ceryngier et al., 2012).

Herein, we report other European case of the harlequin ladybird heavily infected with $H$. virescens. Then the host- $H$. virescens records for the Western Palaearctic and North America are analyzed chronologically and possible mechanisms responsible for the establishment and rapid expansion of the recently emerged $H$. axyridis- $H$. virescens association determined. Finally, we speculate on potential consequences of this novel association for the further spread of the parasite.

\section{CASE REPORT}

On a sunny day in mid-January 2010, an aggregation of H. axyridis individuals was spotted on an outside wall of a building on the campus of Justus-Liebig University, Giessen, Germany $\left(50^{\circ} 34^{\prime} \mathrm{N}, 8^{\circ} 40^{\prime} \mathrm{E}\right)$. Superficial examination of this aggregation showed that many of the beetles were heavily infected with laboulbenialean parasites. The beetles were therefore collected and subsequently killed by freezing at $-80^{\circ} \mathrm{C}$. Later on they were sexed and checked under stereoscopic microscope for infection with fungus, which was identified as $H$. virescens. For infected individuals, the numbers of thalli were counted and their location on the host noted.

Altogether, $134 \mathrm{H}$. axyridis individuals were collected, of which $106(79.1 \%)$ were infected with $H$. virescens. The percentage infection of females (59 out of 74 individuals infected $=79.7 \%$ ) was very similar to that of males (47 out of 60 individuals infected $=78.3 \%$ ). On average, there were more thalli on males than females (63.4 thalli per male vs. 30.9 thalli per female), but this difference was not significant (Mann-Whitney U-test: $Z=$ $-0.91, \mathrm{P}=0.36$, Fig. 1).

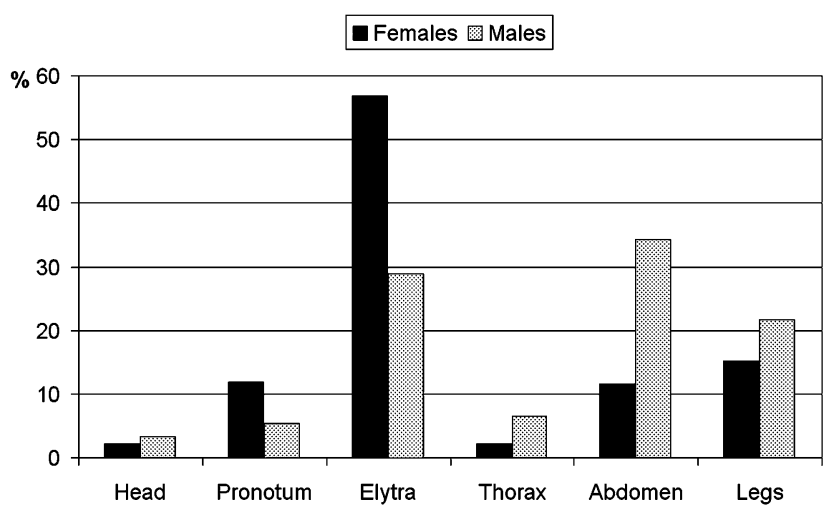

Fig. 2. Distribution of Hesperomyces virescens thalli on male and female Harmonia axyridis hosts.

H. virescens thalli were found on various parts of the hosts' body and were statistically significantly differently distributed on male and female hosts (chi-square test: $\chi^{2}=$ 581.3, $\mathrm{df}=5, \mathrm{P}<0.001$ ) (Fig. 2). In females, the majority of thalli $(57 \%)$ were located on the elytra, while in males on the ventral surface of the abdomen (34\%), but also frequently on the elytra (29\%) and legs $(22 \%)$. This difference indicates that an important but not the only way in which $H$. virescens is transmitted between hosts is during mating. The importance of mating for the transmission of the parasite is reported by other researchers (Welch et al., 2001; Garcés \& Williams, 2004; Harwood et al., 2006a; Riddick, 2006) along with other kinds of direct contact between hosts, especially when they aggregate during winter (Riddick \& Schaefer, 2005; Nalepa \& Weir, 2007).

\section{NEWLY EMERGENT HOST-PARASITE ASSOCIATION}

Non native species invading new areas often experience the loss of parasites through a process called "enemy release", and the opposite process, i.e. the acquisition of parasites native to invaded areas is less frequent (Prenter et al., 2004; Torchin \& Mitchell, 2004). The association between Harmonia axyridis and Hesperomyces virescens is an example of the latter, less frequent, process. The case described above can be included with an increasing body of evidence that the invasive populations of the harlequin ladybird are not only susceptible to some native parasites such as $H$. virescens, the mite Coccipolipus hippodamiae (McDaniel \& Morrill) (Rhule et al., 2010; Riddick, 2010) and allantonematid nematodes (Harding et al., 2011; Roy et al., 2011b; Poinar \& Steenberg, 2012), but also contribute to their dispersal, increase in prevalence and intensity of infection.

The importance of the harlequin ladybird for the spread of $H$. virescens is illustrated by the analysis of past and present records of the latter in the Western Palaearctic region (Table 1) and, especially, in North America (Table 2). Early records of $H$. virescens in the Western Palaearctic are scanty and limited to the Mediterranean Basin (Israel, Morocco, south-eastern France and Spain). In that period, the most frequently reported host of $H$. virescens was Chilocorus bipustulatus (L.). From the 
TABLE 1. Details of the records of Hesperomyces virescens for the Western Palaearctic region.

\begin{tabular}{|c|c|c|c|c|c|}
\hline Date $^{1}$ & Region & Coordinates & $\begin{array}{c}\text { Year } \\
\text { average } \\
\text { temp. }\left({ }^{\circ} \mathrm{C}\right)^{2}\end{array}$ & Host & Reference \\
\hline 1934 & Rehovot (Israel) & $31^{\circ} 54^{\prime} \mathrm{N}, 34^{\circ} 49^{\prime} \mathrm{E}$ & 19 & Chilocorus bipustulatus & Hecht (1936) \\
\hline before 1937 & Casablanca (Morocco) & $33^{\circ} 32^{\prime} \mathrm{N}, 07^{\circ} 35^{\prime} \mathrm{E}$ & 17 & Chilocorus bipustulatus & Maire \& Werner (1937) \\
\hline $1961-62$ & southeastern France & $\sim 44^{\circ} \mathrm{N}, 07^{\circ} \mathrm{E}$ & 15 & Adalia decempunctata & Iperti (1964) \\
\hline $1960 \mathrm{~s}$ & southeastern France & $\sim 44^{\circ} \mathrm{N}, 07^{\circ} \mathrm{E}$ & 15 & Adalia bipunctata & $\begin{array}{l}\text { G. Iperti, unpubl. } \\
\text { (in Hodek, 1973) }\end{array}$ \\
\hline spring 1964 & Kfar Warburg (Israel) & $31^{\circ} 43^{\prime} \mathrm{N}, 34^{\circ} 44^{\prime} \mathrm{E}$ & 24.9 & Chilocorus bipustulatus & Benjamin (1989) \\
\hline 1965 & Kfar Warburg (Israel) & $31^{\circ} 43^{\prime} \mathrm{N}, 34^{\circ} 44^{\prime} \mathrm{E}$ & 24.9 & Chilocorus bipustulatus & Applebaum et al. (1971) \\
\hline 1966 & Rehovot (Israel) & $31^{\circ} 54^{\prime} \mathrm{N}, 34^{\circ} 49^{\prime} \mathrm{E}$ & 19 & Chilocorus bipustulatus & Kamburov et al. (1967) \\
\hline 1966 & Rosh Hanikra (Israel) & $33^{\circ} 05^{\prime} \mathrm{N}, 35^{\circ} 06^{\prime} \mathrm{E}$ & 23.4 & Chilocorus bipustulatus & Kamburov et al. (1967) \\
\hline 1966 & Ashqelon (Israel) & $31^{\circ} 40^{\prime} \mathrm{N}, 34^{\circ} 33^{\prime} \mathrm{E}$ & 24.9 & Chilocorus bipustulatus & Kamburov et al. (1967) \\
\hline 1970 & Kfar Warburg (Israel) & $31^{\circ} 43^{\prime} \mathrm{N}, 34^{\circ} 44^{\prime} \mathrm{E}$ & 24.9 & Chilocorus bipustulatus & Applebaum et al. (1971) \\
\hline 1970 & Givat Brenner (Israel) & $31^{\circ} 52^{\prime} \mathrm{N}, 34^{\circ} 48^{\prime} \mathrm{E}$ & 19 & Chilocorus bipustulatus & Applebaum et al. (1971) \\
\hline before 1974 & Saint-Martin-de-Crau (France) & $43^{\circ} 38^{\prime} \mathrm{N}, 04^{\circ} 49^{\prime} \mathrm{E}$ & 15 & $\begin{array}{c}\text { Psyllobora } \\
\text { vigintiduopunctata }\end{array}$ & Balazuc (1974) \\
\hline 1985 & Santa Fé del Montseny (Spain) & $41^{\circ} 44^{\prime} \mathrm{N}, 02^{\circ} 27^{\prime} \mathrm{E}$ & 14.3 & $\begin{array}{c}\text { Propylea } \\
\text { quatuordecimpunctata }\end{array}$ & Santamaria (1989) \\
\hline 1994 & Knokke-Heist (Belgium) & $51^{\circ} 20^{\prime} \mathrm{N}, 03^{\circ} 17^{\prime} \mathrm{E}$ & 10 & $\begin{array}{c}\text { Psyllobora } \\
\text { vigintiduopunctata }\end{array}$ & De Kesel (2011) \\
\hline before 1996 & London (England) & $51^{\circ} 31^{\prime} \mathrm{N}, 06^{\circ} 55^{\prime} \mathrm{E}$ & 10 & Adalia bipunctata & Weir \& Beakes (1996) \\
\hline $1995-97$ & Berlin (Germany) & $52^{\circ} 30^{\prime} \mathrm{N}, 13^{\circ} 25^{\prime} \mathrm{E}$ & 9 & Adalia bipunctata & Webberley et al. (2006) \\
\hline 1996 & Braunschweig (Germany) & $52^{\circ} 16^{\prime} \mathrm{N}, 10^{\circ} 30^{\prime} \mathrm{E}$ & 8 & Adalia bipunctata & Webberley et al. (2006) \\
\hline 1996 & Parma (Italy) & $44^{\circ} 48^{\prime} \mathrm{N}, 10^{\circ} 20^{\prime} \mathrm{E}$ & 11 & Adalia bipunctata & Webberley et al. (2006) \\
\hline 1996 & Novara (Italy) & $45^{\circ} 27^{\prime} \mathrm{N}, 08^{\circ} 37^{\prime} \mathrm{E}$ & 11.5 & Adalia bipunctata & Webberley et al. (2006) \\
\hline $1997-2005$ & Bayreuth (Germany) & $49^{\circ} 57^{\prime} \mathrm{N}, 11^{\circ} 34^{\prime} \mathrm{E}$ & 7 & Adalia bipunctata & Webberley et al. (2006) \\
\hline 1998 & $\begin{array}{l}\text { London and surroundings } \\
\text { (England) }\end{array}$ & $\sim 51^{\circ} 30^{\prime} \mathrm{N}, 07^{\circ} 30^{\prime} \mathrm{E}$ & 10 & Adalia bipunctata & Welch et al. (2001) \\
\hline 1999 & $\begin{array}{l}\text { London and surroundings } \\
\text { (England) }\end{array}$ & $\sim 51^{\circ} 30^{\prime} \mathrm{N}, 07^{\circ} 30^{\prime} \mathrm{E}$ & 10 & Adalia bipunctata & Welch et al. (2001) \\
\hline 1999 & Vienna (Austria) & $48^{\circ} 12^{\prime} \mathrm{N}, 16^{\circ} 22^{\prime} \mathrm{E}$ & 10.2 & Adalia bipunctata & Christian (2001) \\
\hline 2000 & Vienna (Austria) & $48^{\circ} 12^{\prime} \mathrm{N}, 16^{\circ} 22^{\prime} \mathrm{E}$ & 10.2 & Adalia bipunctata & Christian (2001) \\
\hline 2001 & Vienna (Austria) & $48^{\circ} 12^{\prime} \mathrm{N}, 16^{\circ} 22^{\prime} \mathrm{E}$ & 10.2 & Adalia bipunctata & Christian (2001) \\
\hline 2001 & Sannicandro Garganico (Italy) & $41^{\circ} 50^{\prime} \mathrm{N}, 15^{\circ} 34^{\prime} \mathrm{E}$ & 11.4 & Adalia decempunctata & Castaldo et al. (2004) \\
\hline 2001 & Perama (Greece) & $39^{\circ} 41^{\prime} \mathrm{N}, 20^{\circ} 51^{\prime} \mathrm{E}$ & 14.3 & $\begin{array}{c}\text { Coccinula } \\
\text { quatuordecimpustulata }\end{array}$ & Castaldo et al. (2004) \\
\hline 2001 & Amfithea (Greece) & $39^{\circ} 41^{\prime} \mathrm{N}, 20^{\circ} 52^{\prime} \mathrm{E}$ & 14.3 & $\begin{array}{c}\text { Tytthaspis } \\
\text { sedecimpunctata }\end{array}$ & Castaldo et al. (2004) \\
\hline 2002 & Stockholm (Sweden) & $59^{\circ} 20^{\prime} \mathrm{N}, 18^{\circ} 04^{\prime} \mathrm{E}$ & 6 & Adalia bipunctata & Webberley et al. (2006) \\
\hline 2003 & Lyon (France) & $45^{\circ} 46^{\prime} \mathrm{N}, 04^{\circ} 50^{\prime} \mathrm{E}$ & 11 & Adalia bipunctata & Webberley et al. (2006) \\
\hline before 2006 & Utrecht (the Netherlands) & $52^{\circ} 05^{\prime} \mathrm{N}, 05^{\circ} 06^{\prime} \mathrm{E}$ & 8 & Adalia bipunctata & Webberley et al. (2006) \\
\hline winter $2006 / 2007$ & Meise (Belgium) & $50^{\circ} 57^{\prime} \mathrm{N}, 04^{\circ} 18^{\prime} \mathrm{E}$ & 10 & Harmonia axyridis & De Kesel (2011) \\
\hline 2007 & Warsaw (Poland) & $52^{\circ} 09^{\prime} \mathrm{N}, 21^{\circ} 03^{\prime} \mathrm{E}$ & 8 & Adalia bipunctata & $\begin{array}{l}\text { M.W. Kozlowski } \\
\text { (pers. comm.) }\end{array}$ \\
\hline winter $2007 / 2008$ & Copenhagen (Denmark) & $55^{\circ} 41^{\prime} \mathrm{N}, 12^{\circ} 34^{\prime} \mathrm{E}$ & 8 & Adalia bipunctata & $\begin{array}{c}\text { Steenberg \& Harding } \\
\text { (2010) }\end{array}$ \\
\hline 2008 & De Kaaistoep (the Netherlands) & $51^{\circ} 35^{\prime} \mathrm{N}, 05^{\circ} 03^{\prime} \mathrm{E}$ & 9 & Harmonia axyridis & Haelewaters et al. (2012) \\
\hline spring 2009 & Hohenstein (Germany) & $50^{\circ} 12^{\prime} \mathrm{N}, 08^{\circ} 06^{\prime} \mathrm{E}$ & 10 & Harmonia axyridis & $\begin{array}{c}\text { Steenberg \& Harding } \\
(2010)\end{array}$ \\
\hline 2009 & De Kaaistoep (the Netherlands) & $51^{\circ} 35^{\prime} \mathrm{N}, 05^{\circ} 03^{\prime} \mathrm{E}$ & 9 & Harmonia axyridis & Haelewaters et al. (2012) \\
\hline Jan. 2010 & Giessen (Germany) & $50^{\circ} 34^{\prime} \mathrm{N}, 08^{\circ} 40^{\prime} \mathrm{E}$ & 8 & Harmonia axyridis & this paper \\
\hline 2010 & De Kaaistoep (the Netherlands) & $51^{\circ} 35^{\prime} \mathrm{N}, 05^{\circ} 03^{\prime} \mathrm{E}$ & 9 & Harmonia axyridis & Haelewaters et al. (2012) \\
\hline Dec. 2010 & Ukkel (Belgium) & $50^{\circ} 48^{\prime} \mathrm{N}, 04^{\circ} 20^{\prime} \mathrm{E}$ & 10 & Harmonia axyridis & De Kesel (2011) \\
\hline Feb. 2011 & Brasschaat (Belgium) & $51^{\circ} 18^{\prime} \mathrm{N}, 04^{\circ} 30^{\prime} \mathrm{E}$ & 10 & Harmonia axyridis & De Kesel (2011) \\
\hline Feb.-Mar. 2011 & Meise (Belgium) & $50^{\circ} 57^{\prime} \mathrm{N}, 04^{\circ} 18^{\prime} \mathrm{E}$ & 10 & Harmonia axyridis & De Kesel (2011) \\
\hline Mar. 2011 & Mechelen (Belgium) & $51^{\circ} 01^{\prime} \mathrm{N}, 04^{\circ} 28^{\prime} \mathrm{E}$ & 10 & Harmonia axyridis & De Kesel (2011) \\
\hline Sept. 2011 & Winchester (England) & $51^{\circ} 04^{\prime} \mathrm{N}, 01^{\circ} 18^{\prime} \mathrm{E}$ & 9 & Chilocorus renipustulatus & Hubble (2011) \\
\hline May 2013 & České Budejovice (Czech Rep.) & $48^{\circ} 58^{\prime} \mathrm{N}, 14^{\circ} 28^{\prime} \mathrm{E}$ & 8 & Harmonia axyridis & P. Ceryngier, unpubl. \\
\hline
\end{tabular}

${ }^{1}$ The notation "before + year of publication" is used when the date of the record is not given in the paper; a range of years is used when the precise date is not given but the period of study is; if records for more than one year are reported in a given paper, each of these years is treated as a separate record. ${ }^{2}$ Many years' average annual temperature recorded at the weather station nearest to the reported locality (according to www.weatherbase.com/). 
TABLE 2. Details of the records of Hesperomyces virescens for North America.

\begin{tabular}{|c|c|c|c|c|c|}
\hline Date $^{1}$ & Region & Coordinates & $\begin{array}{c}\text { Year } \\
\text { average } \\
\text { temp. }\left({ }^{\circ} \mathrm{C}\right)^{2}\end{array}$ & Host & Reference \\
\hline before 1891 & Los Angeles, California & $34^{\circ} 03^{\prime} \mathrm{N}, 118^{\circ} 14^{\prime} \mathrm{W}$ & 18.3 & Chilocorus stigma & Thaxter (1891) \\
\hline before 1931 & Auburn, Alabama & $32^{\circ} 36^{\prime} \mathrm{N}, 85^{\circ} 00^{\prime} \mathrm{W}$ & 18 & Hippodamia convergens & Thaxter (1931) \\
\hline Jul.-Nov. 2002 & Wooster, Ohio & $40^{\circ} 48^{\prime} \mathrm{N}, 81^{\circ} 56^{\prime} \mathrm{W}$ & 9 & Harmonia axyridis & Garcés \& Williams (2004) \\
\hline Dec. 2002 & Mt. Gretna, Pennsylvania & $40^{\circ} 15^{\prime} \mathrm{N}, 76^{\circ} 28^{\prime} \mathrm{W}$ & 10.8 & Harmonia axyridis & Riddick \& Schaefer (2005) \\
\hline Jul.-Oct. 2003 & Oktibbeha Co., Mississippi & $33^{\circ} 27^{\prime} \mathrm{N}, 88^{\circ} 48^{\prime} \mathrm{W}$ & 17 & Harmonia axyridis & Riddick (2006) \\
\hline Oct. 2003 & Weaverville, North Carolina & $35^{\circ} 43^{\prime} \mathrm{N}, 82^{\circ} 27^{\prime} \mathrm{W}$ & 13.5 & Harmonia axyridis & Nalepa \& Weir (2007) \\
\hline Oct. 2003 & Cary, North Carolina & $35^{\circ} 47^{\prime} \mathrm{N}, 78^{\circ} 44^{\prime} \mathrm{W}$ & 15.8 & Harmonia axyridis & Nalepa \& Weir (2007) \\
\hline Dec. 2003 & Cary, North Carolina & $35^{\circ} 47^{\prime} \mathrm{N}, 78^{\circ} 44^{\prime} \mathrm{W}$ & 15.8 & Harmonia axyridis & Nalepa \& Weir (2007) \\
\hline Mar. 2004 & Cary, North Carolina & $35^{\circ} 47^{\prime} \mathrm{N}, 78^{\circ} 44^{\prime} \mathrm{W}$ & 15.8 & Harmonia axyridis & Nalepa \& Weir (2007) \\
\hline May-Aug. 2004 & Silver Lake Farm, Kentucky & $38^{\circ} 13^{\prime} \mathrm{N}, 84^{\circ} 49^{\prime} \mathrm{W}$ & 12.2 & Harmonia axyridis & Harwood et al. (2006a) \\
\hline May-Aug. 2004 & Silver Lake Farm, Kentucky & $38^{\circ} 13^{\prime} \mathrm{N}, 84^{\circ} 49^{\prime} \mathrm{W}$ & 12.2 & $\begin{array}{c}\text { Psyllobora } \\
\text { vigintimaculata }\end{array}$ & Harwood et al. (2006a) \\
\hline May-Aug. 2004 & Silver Lake Farm, Kentucky & $38^{\circ} 13^{\prime} \mathrm{N}, 84^{\circ} 49^{\prime} \mathrm{W}$ & 12.2 & $\begin{array}{l}\text { Brachiacantha } \\
\text { quadripunctata }\end{array}$ & Harwood et al. (2006a) \\
\hline May-Aug. 2004 & Silver Lake Farm, Kentucky & $38^{\circ} 13^{\prime} \mathrm{N}, 84^{\circ} 49^{\prime} \mathrm{W}$ & 12.2 & Cycloneda munda & Harwood et al. (2006a) \\
\hline Jun.-Oct. 2004 & Oktibbeha Co., Mississippi & $33^{\circ} 27^{\prime} \mathrm{N}, 88^{\circ} 48^{\prime} \mathrm{W}$ & 17 & Harmonia axyridis & Riddick (2006) \\
\hline 2004 & Lexington, Kentucky & $38^{\circ} 02^{\prime} \mathrm{N}, 84^{\circ} 30^{\prime} \mathrm{W}$ & 12 & $\begin{array}{c}\text { Coccinella } \\
\text { septempunctata }\end{array}$ & Harwood et al. (2006b) \\
\hline 2005 & Lexington, Kentucky & $38^{\circ} 02^{\prime} \mathrm{N}, 84^{\circ} 30^{\prime} \mathrm{W}$ & 12 & $\begin{array}{c}\text { Coccinella } \\
\text { septempunctata }\end{array}$ & Harwood et al. (2006b) \\
\hline 2005 & Frankfort, Kentucky & $38^{\circ} 12^{\prime} \mathrm{N}, 84^{\circ} 52^{\prime} \mathrm{W}$ & 13.1 & $\begin{array}{c}\text { Coccinella } \\
\text { septempunctata }\end{array}$ & Harwood et al. (2006b) \\
\hline 2005 & Brookings, South Dakota & $44^{\circ} 19^{\prime} \mathrm{N}, 96^{\circ} 48^{\prime} \mathrm{W}$ & 6 & Harmonia axyridis & Harwood et al. (2006b) \\
\hline 2005 & Fayetteville, Arkansas & $36^{\circ} 04^{\prime} \mathrm{N}, 94^{\circ} 09^{\prime} \mathrm{W}$ & 14 & Harmonia axyridis & Harwood et al. (2006b) \\
\hline 2005 & Perkins, Oklahoma & $35^{\circ} 58^{\prime} \mathrm{N}, 97^{\circ} 02^{\prime} \mathrm{W}$ & 15.4 & Harmonia axyridis & Harwood et al. (2006b) \\
\hline 2005 & State College, Pennsylvania & $40^{\circ} 47^{\prime} \mathrm{N}, 77^{\circ} 52^{\prime} \mathrm{W}$ & 9 & Harmonia axyridis & Harwood et al. (2006b) \\
\hline 2005 & Jefferson Co., West Virginia & $39^{\circ} 19^{\prime} \mathrm{N}, 77^{\circ} 53^{\prime} \mathrm{W}$ & 11.7 & Harmonia axyridis & Harwood et al. (2006b) \\
\hline 2005 & Lexington, Kentucky & $38^{\circ} 02^{\prime} \mathrm{N}, 84^{\circ} 30^{\prime} \mathrm{W}$ & 12 & Harmonia axyridis & Harwood et al. (2006b) \\
\hline 2005 & Frankfort, Kentucky & $38^{\circ} 12^{\prime} \mathrm{N}, 84^{\circ} 52^{\prime} \mathrm{W}$ & 13.1 & Harmonia axyridis & Harwood et al. (2006b) \\
\hline Apr.-Oct. 2007 & Byron, Georgia & $32^{\circ} 39^{\prime} \mathrm{N}, 83^{\circ} 46^{\prime} \mathrm{W}$ & 17.6 & Harmonia axyridis & Riddick \& Cottrell (2010) \\
\hline Apr.-Oct. 2007 & Byron, Georgia & $32^{\circ} 39^{\prime} \mathrm{N}, 83^{\circ} 46^{\prime} \mathrm{W}$ & 17.6 & Hippodamia convergens & Riddick \& Cottrell (2010) \\
\hline Apr.-Oct. 2007 & Byron, Georgia & $32^{\circ} 39^{\prime} \mathrm{N}, 83^{\circ} 46^{\prime} \mathrm{W}$ & 17.6 & Olla v-nigrum & Riddick \& Cottrell (2010) \\
\hline Dec. 2007 & Leland, Mississippi & $33^{\circ} 24^{\prime} \mathrm{N}, 90^{\circ} 59^{\prime} \mathrm{W}$ & 17.5 & Harmonia axyridis & Riddick (2010) \\
\hline Dec. 2008 & Grenada, Mississippi & $33^{\circ} 47^{\prime} \mathrm{N}, 89^{\circ} 46^{\prime} \mathrm{W}$ & 17 & Harmonia axyridis & Riddick (2010) \\
\hline Dec. 2008 & Stoneville, Mississippi & $33^{\circ} 27^{\prime} \mathrm{N}, 90^{\circ} 55^{\prime} \mathrm{W}$ & 17.5 & Harmonia axyridis & Riddick (2010) \\
\hline Dec. 2008 & Benoit, Mississippi & $33^{\circ} 40^{\prime} \mathrm{N}, 91^{\circ} 08^{\prime} \mathrm{W}$ & 17.3 & Harmonia axyridis & Riddick (2010) \\
\hline Jan. 2009 & $\begin{array}{c}\text { Delta National Forest, } \\
\text { Mississippi }\end{array}$ & $32^{\circ} 49^{\prime} \mathrm{N}, 90^{\circ} 49^{\prime} \mathrm{W}$ & 17.3 & Harmonia axyridis & Riddick (2010) \\
\hline
\end{tabular}

1,2 as in Table 1.

mid-1990s, this parasite is recorded more frequently and usually from much more northerly localities in Europe, often in towns and cities, which as a rule are warmer than surrounding rural areas and hence termed urban heat islands (Oke, 1973). The effect of such an urban heat island on $H$. virescens was demonstrated by Welch et al. (2001). They found a clear negative correlation between the prevalence of this parasite on the two-spot ladybird, Adalia bipunctata (L.), and distance of the sampling site from the centre of London. Up to a $50 \%$ prevalence was recorded in the centre while some $25 \mathrm{~km}$ from the centre, outside the urban area, no infection was detected. The relatively recent European records of $H$. virescens mostly refer to A. bipunctata as the host, but the majority of most recent observations are for a novel host, $H$. axyridis. The European data on the prevalence of $H$. virescens on $H$. axyridis clearly show it has increased over time. In sam- ples of $H$. axyridis from light-traps collected over several years at De Kaaistoep (the Netherlands), there was no evidence of infection in 2007 , but $0.4 \%$ were infected in 2008, 3.9\% in 2009 and 7.2\% in 2010 (Haelewaters et al., 2012). Infection of $H$. axyridis with $H$. virescens in winter aggregations increased from $0.5 \%$ in winter 2006/2007 (Meise near Brussels, De Kesel, 2011) and 0.9\% in spring 2009 (Hohenstein near Frankfurt, Steenberg \& Harding, 2010 ) to $79.1 \%$ in January 2010 (Giessen, this study) and 96.5\% in February-March 2011 (Meise, De Kesel, 2011).

In North America, the connection between spread of the harlequin ladybird and expansion of $H$. virescens is even clearer (Table 2). The only North American records of ladybirds infected with $H$. virescens preceding the invasion by $H$. axyridis are those reported by Thaxter (1891, 1931) from California and Alabama of Chilocorus stigma (Say) and Hippodamia convergens (Guérin- 
Méneville), respectively. More than 70 years after the latter of Thaxter's reports, $H$. virescens is a common parasite of $H$. axyridis in a considerable area of the United States with the reported localities ranging between about $33^{\circ} \mathrm{N}$ (Mississippi and Georgia) and $44^{\circ} \mathrm{N}$ (Brookings in South Dakota). Apart from the numerous records of $H$. axyridis as a host of $H$. virescens, there are several recent reports of other species of ladybird being infected, but the prevalence of this parasite on these species is much lower than on $H$. axyridis (Harwood et al., 2006a, b; Riddick \& Cottrell, 2010).

To conclude, both in Europe and North America, there has been a considerable northward range shift of the fungus over the last few years. In addition, $H$. axyridis, a ladybird that has recently become established on both continents, is a highly suitable and susceptible host of $H$. virescens and currently its major host.

\section{HOW DID H. AXYRIDIS ACQUIRE H. VIRESCENS IN INVADED AREAS?}

A relatively long period of time elapsed between the harlequin ladybird becoming established in North America and the first records of $H$. virescens infections of $H$. axyridis. The first feral North American population of H. axyridis was recorded in 1988 (Chapin \& Brou, 1991) and the first $H$. virescens infection of this ladybird in 2002 (Garcés \& Williams, 2004), that is, a period of 14years elapsed between these two events. In Europe, however, the time delay was half that recorded in North America: from 1999, when the first feral $H$. axyridis population was reported by Tolasch (2002) to 2006, when the first infection of $H$. axyridis by $H$. virescens was reported by De Kesel (2011).

That there was a delay may indicate that the fungus required some time to adapt to the novel host and/or transfer of the fungus from one host species to another generally occurs infrequently. The latter possibility seems quite probable, taking into account the unique life cycles of the laboulbenialean fungi, which is likely to hamper their transmission between hosts belonging to different species. Laboulbeniales do not produce conidial spores, sclerotia or other structures enabling to survive in unfavourable conditions. They can only propagate by means of short-lived viscous ascospores (De Kesel, 1995a), which after release from the perithecium, must promptly adhere to the cuticle of a host, germinate and produce new thalli (Tavares, 1979; Weir \& Hammond, 1997; Majewski, 2008). Due to this, most laboulbenialean parasites can only be transmitted between hosts during direct body contact, usually during copulation (De Kesel, 1995b; Weir \& Hammond, 1997; Majewski, 2008). Sexual transmission is probably the most important way in which $H$. virescens is transmitted, and this is often indicated by the different distribution of the parasite thalli on male and female hosts. Males tend to bear most thalli on their ventroposterior surface and females on their dorsoposterior surface (Welch et al., 2001; Garcés \& Williams, 2004; Harwood et al., 2006a; Riddick, 2006; this study). Of the non-sexual direct contacts among hosts that may result in parasite transmission probably the most important is that which occurs in overwintering aggregations (Riddick \& Schaefer, 2005; Nalepa \& Weir, 2007). In the initial transfer of $H$. virescens to $H$. axyridis both sexual and non-sexual bodily contacts among hosts could have played a part. Interspecific matings or mating attempts occasionally occur in ladybirds (Majerus, 1997; Nedved \& Honek, 2012) and such incidents may be associated with parasite transmissions (Majerus, 1997). On the other hand, ladybirds sometimes overwinter in mixed (heterospecific) aggregations (Hodek, 2012), which may also facilitate interspecific transmissions. However, although there is some data (De Kesel, 1996) that indicate that interspecific transmission may easily occur in some Laboulbeniales, as recently shown by Cottrell \& Riddick (2012), transmission of $H$. virescens between hosts belonging to different species is rare, even if infected and healthy ladybirds are confined in the limited space of a Petri dish, whereas, when infected and uninfected individuals of the same species of ladybird $(H$. axyridis or Olla v-nigrum (Mulsant)) are similarly confined parasite transmission frequently occurs. The obstacles to interspecific transmission of $H$. virescens would have delayed the initial transfer of the fungus to $H$. axyridis. In Europe this initial transfer probably happened sooner than in the United States, possibly because many of the areas of Europe invaded by $H$. axyridis were already colonized by relatively abundant populations of $H$. virescens, mainly infecting a very common host species, A. bipunctata (Table 1 ). As $A$. bipunctata and $H$. axyridis have very similar ecological niches (Harmon et al., 2007; Adriaens et al., 2008; Roy et al., 2012), various interactions between them, including body contacts, are probably frequent. The two species are known to form mixed winter aggregations, and in such aggregations individuals heavily infected with $H$. virescens occur (Steenberg \& Harding, 2010).

\section{WHAT MAKES H. AXYRIDIS AN EXCEPTIONALLY SUITABLE HOST?}

The enemy release hypothesis assumes that an invasive species can gain a numerical advantage over native species because it is less limited by natural enemies than the native species. In addition, according to the so called evolution of increased competitive ability hypothesis, invaders can respond to a lack of natural enemies by reallocating resources from defense to growth and/or reproduction (Blossey \& Nötzold, 1995). It is supposed that both these mechanisms may contribute to $H$. axyridis invasiveness (Roy et al., 2011a, b; Sloggett, 2012). However, as pointed out by Sloggett (2012), the initial benefit for the invader from the evolution of increased competitive ability may in a later phase of the invasion change into a disadvantage when the invader becomes more susceptible to native enemies. This may partly explain the recent success of $H$. virescens in utilizing $H$. axyridis as a host. However, for the establishment of a stable hostparasite association, the host has to be both susceptible to infection and suitable for the parasite. It seems that cer- 
tain features of $H$. axyridis make it more suitable for certain parasites, including $H$. virescens, than most other ladybirds.

The harlequin ladybird is a highly ubiquitous, polyphagous (Hodek \& Evans, 2012), multivoltine (Koch, 2003; Hodek, 2012) and promiscuous species (Osawa, 1994) that forms large aggregations during winter (Koch, 2003; Wang et al., 2011). Each of these features alone is not unique among ladybirds, but taken together make $H$. axyridis unique in respect of its potential suitability for some parasites, especially those that require close contact between hosts for efficient transmission. As a common and widespread generalist, $H$. axyridis can produce very large populations capable of hosting abundant populations of parasites, which due to the promiscuity of $H$. axyridis, may be effectively transmitted during mating. Transmission between different generations of the host can be achieved by inter-generational host matings that are likely to occur in populations of multivoltine hosts with overlapping generations (Welch et al., 2001; Knell \& Webberley, 2004). In H. axyridis, its multivoltine life cycle and long adult life may result in a considerable overlap between generations. According to Savoiskaya (1970, ref. in Nedved \& Honek, 2012), H. axyridis adults may live and reproduce for periods as long as three years. Overwintering of $H$. axyridis in mass aggregations may further facilitate the spread of parasites.

Because of the attributes mentioned above, $H$. axyridis has contributed considerably to the rapid expansion in the distribution of $H$. virescens. However, other parasites may also experience similar novel host driven expansions. Recently, $H$. axyridis was recorded as a host of the ectoparasitic mite $C$. hippodamiae in North America (Mississippi, USA) (Riddick, 2010) and Europe (northcentral Poland) (Rhule et al., 2010). Our unpublished data indicate that this host-parasite association is also quite common in other regions in Poland. C. hippodamiae has a similar mode of transmission to $H$. virescens. Both are mainly sexually transmitted (Ceryngier et al., 2012) and, therefore, for the spread of both these species $H$. axyridis should be similarly suitable. However, the effects of these two parasites on their hosts are quite different. While $H$. virescens is thought to be relatively harmless (Weir \& Beakes, 1996; Nalepa \& Weir, 2007, but see also Kamburov et al., 1967), C. hippodamiae causes sterility of female hosts (Hurst et al., 1995; Webberley et al., 2004) and increases winter mortality, especially of male hosts (Webberley \& Hurst, 2002). Thus, the latter is likely to be an important factor limiting the abundance of ladybirds, which may be desirable in terms of the biological control of the invasive $H$. axyridis.

Other parasites that have recently been discovered infecting $H$. axyridis, both in Europe and North America, are nematodes belonging to the family Allantonematidae. A recently described species, Parasitylenchus bifurcatus Poinar \& Steenberg is recorded infecting a Danish population of $H$. axyridis since 2009 (Harding et al., 2011; Poinar \& Steenberg, 2012) and in 2009 allantonematid nematodes were found infecting $H$. axyridis in Minnesota
(USA) (Roy et al., 2011b). In contrast to ectoparasitic Hesperomyces and Coccipolipus, Allantonematidae are endoparasites. The effect of these nematodes on hosts is not directly lethal, although they are recorded as reducing the survival of $H$. axyridis (Poinar \& Steenberg, 2012). It is also suggested (Poinar \& Steenberg, 2012) that allantonematid parasites may severely affect other fitness parameters of their hosts, such as male and female fertility or mating success. With the exception of Howardula sp., which infects A. bipunctata larvae in England (Hariri, 1965), all other reports of Allantonematidae from ladybirds, including those quoted above and older ones of Parasitylenchus coccinellinae Iperti \& van Waerebeke from France (Iperti \& van Waerebeke, 1968) and India (Narsi Reddy \& Narayan Rao, 1984), are of the parasitization of adult beetles, usually those with multivoltine life cycles. This may suggest that, as in $H$. virescens and $C$. hippodamiae, sexual contacts between hosts play a part in the transmission of the allantonematids and, hence, the harlequin ladybird is potentially a very suitable host for these nematodes. The mode of transmission of Parasitylenchus spp. is currently unknown. It is supposed that infective females may penetrate into a new host through its tracheae, soft cuticle between sclerites or reproductive organs (Ceryngier et al., 2012). For this close contact during mating it may facilitate transmission.

\section{CONSEQUENCES OF THE NOVEL HOST-PARASITE ASSOCIATION}

As it is shown above, there has been a considerable increase in the abundance and expansion of the geographical range of $H$. virescens in North America as a result of it acquiring a new host, $H$. axyridis (Table 2). In Europe, an analogous process with another host, i.e. $A$. bipunctata, might have started before the establishment of $H$. axyridis. Before these two waves of $H$. virescens expansion, the majority of records were of parasitization of Chilocorus bipustulatus in North Africa and the Near East (Table 1). It seems that in terms of the suitability for $H$. virescens, the most important common feature of the three main hosts (C. bipustulatus, A. bipunctata and $H$. axyridis) is a multivoltine life cycle. In the Near East, $C$. bipustulatus can produce up to 4-5 generations per year with considerable overlap between generations (Hecht, 1936), which facilitates the efficient between-generation transmission of the fungus. In northern Italy, both $A$. bipunctata and $H$. axyridis completed four generations per year in semi-field experiment (Bazzocchi et al., 2004). Similarly, H. axyridis completed four overlapping generations in outdoor experiments in Greece (Katsoyannos et al., 1997). Number of generations per year decreases with increase in climate severity, but even in colder areas $H$. axyridis is regularly at least bivoltine, with the last generation developing much later in the season than in other ladybirds (juvenile stages occur in the field in October or even November) (LaMana \& Miller, 1996; Koch, 2003; Adriaens et al., 2008; Brown et al., 2008). The autumnal abundance of $H$. axyridis recorded year by year throughout its whole invasive range 
has possibly enabled its newly acquired parasite to substantially expand its range toward areas where other potential hosts are univoltine or the second generation develops irregularly and is rarely abundant. Recent climate change may also have affected the range shift of $H$. virescens by modifying the voltinism and overlap in the generations of its hosts. The great increase in the number of European records of $A$. bipunctata- $H$. virescens association in the late 1990 s and early 2000 s (Table 1) may be a consequence of such climate-induced life cycle changes. Other phenomenon supporting the climate change hypothesis is the present spread in Europe of another species of Hesperomyces, H. coccinelloides (Thaxter) Thaxter, which infects minute ladybirds in the subfamily Scymninae (Ceryngier, 2013).

One possible outcome of the commonness of the $H$. axyridis- $H$. virescens association may be an extension in the host range of the latter. Although transmission of $H$. virescens between different host species is not frequent (Cottrell \& Riddick, 2012), mass infections of $H$. axyridis are likely to result in some inter-specific transmissions. In the United States, several new hosts of $H$. virescens were recorded after $H$. axyridis became its main host (Table 2 ).

We may also expect that $H$. virescens will establish and become abundant in populations of $H$. axyridis in other parts of its range, such as South America, Africa or Asia. This may happen through transmissions from the hostparasite associations naturally occurring in these areas or from human-mediated intercontinental dispersal of infected ladybirds. The presence of $H$. virescens in South America (Argentina, Brazil) is documented by Thaxter (1931) and Spegazzini (1917, ref. in Thaxter, 1931), but no records are known from sub-Saharan Africa and continental Asia (except the peripheral Near East). However, as the reported distribution of this fungus is nearly cosmopolitan (Thaxter, 1931; Santamaria et al., 1991; Ceryngier et al., 2012), its natural occurrence in these regions cannot be excluded. On the other hand, the potential of $H$. axyridis for spreading between continents is rather high bearing in mind that the only or main source of all the invasive populations of this species on four continents was the same local population, the first North American feral population from Louisiana (USA) (Lombaert et al., 2010).

An interesting issue is the possible transfer of $H$. virescens and other parasites from invasive $H$. axyridis to its native, Asiatic populations. This may take place when this species in Europe spreads to the east and reaches the natural geographic range of their conspecifics. The western border of its native range is not exactly known, but is thought to be somewhere in the central part of Asia (Iablokoff-Khnzorian, 1982; Koch, 2003; Brown et al., 2011). Some Russian authors, however, report $H$. axyridis much further west, in the Ural Mountains (Tyumaseva, 1997; Pekin, 2007; Khabibullin et al., 2009) or even in the Belgorod region of Russia near its border with Ukraine (Bin'kovskaya, 2004; Orlova-Bienkowskaja, 2013). On the other hand, $H$. axyridis spreading from the west was detected in the Kiev region in Ukraine in 2007
(Verizhnikova, 2011). Thus, it is likely that individuals invading from the west will shortly start to mix with native, non-invasive populations of $H$. axyridis. Apart from the threat of being outcompeted by the invasive strain, the polymorphic natives may suffer from parasites vectored by the former. Among these parasites, it is likely that $H$. virescens will be one of the most important.

ACKNOWLEDGEMENTS. We wish to thank T. Majewski for confirming the identity of the fungus collected in Giessen. We are very grateful to A. De Kesel and an anonymous referee for their very useful comments on the manuscript and to A.F.G. Dixon for linguistic correction. The case study was conducted during the stay of K. Twardowska at Justus-Liebig University, Giessen (Institute of Phytopathology and Applied Zoology), in 2009/2010, funded by the Erasmus Programme.

\section{REFERENCES}

Adriaens T., San Martin y Gomez G. \& Maes D. 2008: Invasion history, habitat preferences and phenology of the invasive ladybird Harmonia axyridis in Belgium. - BioControl 53: $69-88$.

Applebaum S.W., Kfir R., Gerson U. \& Tadmor U. 1971: Studies on the summer decline of Chilocorus bipustulatus in citrus groves of Israel. - Entomophaga 16: 433-444.

BALAzUC J. 1974: Laboubeniales de France (suite et fin). Bull. Mens. Soc. Linn. Soc. Bot. Lyon 43: 346-368.

Bazzocchi G.G., Lanzoni A., Accinelli G. \& Burgio G. 2004: Overwintering, phenology and fecundity of Harmonia axyridis in comparison with native coccinellid species in Italy. BioControl 49: 245-260.

BENJAMIN R.K. 1989: Taxonomy and morphology of Acompsomyces (Laboulbeniales), with notes on two excluded species, Acompsomyces stenichni and Acompsomyces lasiochili. Mem. New York Botan. Gar. 49: 210-232.

Bin'kovskaya O.V. 2004: Coccinellid Beetles of Forest Ecosystems in the South of the Central Russian Upland. Thesis resume, Voronezh State Forestry Engineering Academy, Voronezh, 21 pp. [in Russian].

Blossey B. \& Nötzold R. 1995: Evolution of increased competitive ability in invasive nonindigenous plants: a hypothesis. - J. Ecol. 83: 887-889.

Brown P.M.J., Roy H.E., Rothery P., Roy D.B., Ware R.L. \& Majerus M.E.N. 2008: Harmonia axyridis in Great Britain: analysis of the spread and distribution of a non-native coccinellid. - BioControl 53: 55-67.

Brown P.M.J., Thomas C.E., Lombaert E., Jeffries D.L., Estoup A. \& Lawson Handley L.-J. 2011: The global spread of Harmonia axyridis (Coleoptera: Coccinellidae): distribution, dispersal and routes of invasion. - BioControl 56: 623-641.

Castaldo D., Rossi W. \& Sabatini F. 2004: Contribution to the knowledge of the Laboulbeniales from Greece. - Plant Biosyst. 138: 261-269.

Ceryngier P. 2013: Stethorus pusillus (Coleoptera: Coccinellidae) as a host of the ectoparasitic fungus Hesperomyces coccinelloides (Ascomycota: Laboulbeniales, Laboulbeniaceae) in Poland. - Polish J. Entomol. 82: 13-18.

Ceryngier P., Roy H.E. \& Poland R.L. 2012: Natural enemies of ladybird beetles. In Hodek I., van Emden H.F. \& Honek A. (eds): Ecology and Behaviour of the Ladybird Beetles (Coccinellidae). Blackwell, Chichester, pp. 375-443.

Chapin J.B. \& Brou V.A. 1991: Harmonia axyridis (Pallas), the third species of the genus to be found in the United States 
(Coleoptera: Coccinellidae). — Proc. Entomol. Soc. Wash. 93: $630-635$.

Christian E. 2001: The coccinellid parasite Hesperomyces virescens and further species of the order Laboulbeniales (Ascomycotina) new to Austria. - Ann. Naturhist. Mus. Wien (B) 103: 599-603.

Cottrell T.E. \& Riddick E.W. 2012: Limited transmission of the ectoparasitic fungus Hesperomyces virescens between lady beetles. - Psyche 2012: Article ID 814378, 7 pp.

De Kesel A. 1995a: Relative importance of direct and indirect infection in the transmission of Laboulbenia slackensis (Ascomycetes, Laboulbeniales). - Belg. J. Bot. 128: 124-130.

De Kesel A. 1995b: Population dynamics of Laboulbenia clivinalis Thaxter (Ascomycetes, Laboulbeniales) and sexrelated thallus distribution on its host Clivina fossor (Linnaeus, 1758) (Coleoptera, Carabidae). - Bull. Annls Soc. R. Belge Entomol. 131: 335-348.

De Kesel A. 1996: Host specificity and habitat preference of Laboulbenia slackensis. — Mycologia 88: 565-573.

De Kesel A. 2011: Hesperomyces (Laboulbeniales) and coccinellid hosts. - Sterbeeckia 30: 32-37.

Garcés S. \& Williams R. 2004: First record of Hesperomyces virescens Thaxter (Laboulbeniales: Ascomycetes) on Harmonia axyridis (Pallas) (Coleoptera: Coccinellidae). $-J$. Kans. Entomol. Soc. 77: 156-158.

Haelewaters D. \& De Kesel A. 2011: Laboulbeniales van De Kaaistoep. In Cramer T. \& Van Wielink P. (eds): Natuurstudie in De Kaaistoep. Verslag 2010, 16e onderzoeksjaar. NV Tilburgsche Waterleiding-Maatschappij, KNNVafdeling Tilburg \& Natuurmuseum Brabant, pp. 107-112.

Haelewaters D., van WielinK P., van ZuiJlen J.W., Verbeken A. \& De Kesel A. 2012: New records of Laboulbeniales (Fungi, Ascomycota) for the Netherlands. - Entomol. Ber. 72: $175-183$.

Harding S., Poinar G.O. JR., Dimitrova D.V. \& Steenberg T. 2011: Parasitylenchus sp. (Tylenchomorpha: Allantonematidae) parasitizing field populations of Harmonia axyridis (Coleoptera: Coccinellidae). - Eur. J. Entomol. 108: 487-488.

HARIRI G. 1965: Records of nematode parasites of Adalia bipunctata (L.) (Col., Coccinellidae). - Entomol. Mon. Mag. 101: 132.

Harmon J.P., Stephens E. \& Losey J. 2007: The decline of native coccinellids (Coleoptera: Coccinellidae) in the United States and Canada. - J. Insect Conserv. 11: 85-94.

Harwood J.D., Ricci C., Romani R., Pitz K.M., Weir A. \& OBRYCKI J.J. 2006a: Prevalence and association of the laboulbenialean fungus Hesperomyces virescens (Laboulbeniales: Laboulbeniaceae) on coccinellid hosts (Coleoptera: Coccinellidae) in Kentucky, USA. - Eur. J. Entomol. 103: 799-804.

Harwood J.D., Ricci C., Romani R. \& ObrYcki J.J. 2006b: Historic prevalence of a laboulbenialean fungus infecting introduced coccinellids in the United States. - Antenna 30: 74-79.

Hecht O. 1936: Studies on the biology of Chilocorus bipustulatus (Coleoptera - Coccinellidae) an enemy of the red scale Chrysomphalus aurantii. - Bull. Soc. R. Entomol. Egypte 1936: 299-326.

Hodek I. 1973: Biology of Coccinellidae. Academia, Prague \& Dr W. Junk, The Hague, 260 pp.

Hodek I. 2012: Diapause/dormancy. In Hodek I., van Emden H.F. \& Honek A. (eds): Ecology and Behaviour of the Ladybird Beetles (Coccinellidae). Blackwell, Chichester, pp. 275-342.
Hodek I. \& Evans E.W. 2012: Food relationships. In Hodek I., van Emden H.F. \& Honek A. (eds): Ecology and Behaviour of the Ladybird Beetles (Coccinellidae). Blackwell, Chichester, pp. 141-274.

HubBLe D. 2011: Kidney-spot ladybird Chilocorus renipustulatus (Scriba) (Coccinellidae), a new host for the parasitic fungus Hesperomyces virescens Thaxter (Ascomycetes: Laboulbeniales). - The Coleopterist 20: 135-136.

Hurst G.D.D., Sharpe R.G., Broomfield A.H., Walker L.E., Majerus T.M.O., ZaKharov I.A. \& Majerus M.E.N. 1995: Sexually transmitted disease in a promiscuous insect, Adalia bipunctata. - Ecol. Entomol. 20: 230-236.

Iablokoff-Khnzorian S.M. 1982: Les Coccinelles. Coléoptères - Coccinellidae. Tribu Coccinellini des régions Paléarctique et Orientale. Société Nouvelle des Editions Boubée, Paris, $568 \mathrm{pp}$.

IPERTI G. 1964: Les parasites des Coccinelles aphidiphages dans les Basses-Alpes et les Alpes-Maritimes. - Entomophaga 9: 153-180.

IPERTI G. \& VAN WAerebeKe D. 1968: Description, biologie et importance d'une nouvelle espèce d'Allantonematidae (Nématode) parasite des coccinelles aphidiphages: Parasitylenchus coccinellinae, n. sp. - Entomophaga 13: 107-119.

Kamburov S.S., Nadel D.J. \& KenNeth R. 1967: Observations on Hesperomyces virescens Thaxter (Laboulbeniales), a fungus associated with premature mortality of Chilocorus bipustulatus L. in Israel. - Israel J. Agric. Res. 17: 131-134.

Katsoyannos P., Kontodimas D.C., Stathas G.J. \& Tsartsalis C.T. 1997: Establishment of Harmonia axyridis on citrus and some data on its phenology in Greece. - Phytoparasitica 25: 183-191.

KauR S. \& MukerJI K.G. 2006: The Laboulbeniales (Ascomycetes): distribution and host parasite relationships. In Mukerji K.G. \& Manoharachary C. (eds): Current Concepts in Botany. I.K. International, New Delhi, pp. 19-35.

Khabibullin A.F., Safina I.I. \& Khabibullin V.F. 2009: On coccinellid (Coleoptera: Coccinellidae) fauna of industrial (northern) part of Ufa. - Vest. Mordov. Univ. (Biol.) 2009: 74 [in Russian].

KNell R.J. \& Webberley K.M. 2004: Sexually transmitted diseases of insects: distribution, evolution, ecology and host behaviour. - Biol. Rev. 79: 557-581.

Koch R.L. 2003: The multicolored Asian lady beetle, Harmonia axyridis: A review of its biology, uses in biological control, and non-target impacts. - J. Insect Sci. 3:32, $16 \mathrm{pp}$.

LaMana M.L. \& Miller J.C. 1996: Field observations on Harmonia axyridis Pallas (Coleoptera: Coccinellidae) in Oregon. - Biol. Contr. 6: 232-237.

Lombaert E., Gulllemaud T., Cornuet J.-M., Malausa T., FACON B. \& Estoup A. 2010: Bridgehead effect in the worldwide invasion of the biocontrol harlequin ladybird. - PLoS ONE 5(3): e9743, 7 pp.

Maire R. \& Werner R.G. 1937: Fungi Maroccani. Catalogue raisonné des champignons connus jusqu'ici au Maroc. Mém. Soc. Sci. Nat. Maroc 45: 1-147.

MaJERUS M.E.N. 1997: Interspecific hybridisation in ladybirds (Col.: Coccinellidae). - Entomol. Rec. J. Var. 109: 11-23.

Majewski T. 2008: Atlas of the Geographical Distribution of Fungi in Poland, Fasc. 4. Laboulbeniales. W. Szafer Inst. Bot. Pol. Acad. Sci., Kraków, 240 pp.

NALEPA C.A. \& WeIR A. 2007: Infection of Harmonia axyridis (Coleoptera: Coccinellidae) by Hesperomyces virescens (Ascomycetes: Laboulbeniales): Role of mating status and aggregation behavior. - J. Invert. Pathol. 94: 196-203.

Narsi Reddy Y. \& Narayan Rao P. 1984: First report of Parasitylenchus coccinellae Iperti and Waerebeke (1968) from 
India in two new hosts Menochilus sexmaculatus (F) and Illeis indica Timb. - Riv. Parassitol. 45: 133-137.

Nedved O. \& HoneK A. 2012. Life history and development. In Hodek I., van Emden H.F. \& Honek A. (eds): Ecology and Behaviour of the Ladybird Beetles (Coccinellidae). Blackwell, Chichester, pp. 54-109.

OKe T.R. 1973: City size and the urban heat island. Atmos. Environ. 7: 769-779.

OrLova-BIENKOWSKAJA M.JA. 2013: The dangerous invasive harlequin ladybird Harmonia axyridis (Pallas, 1773) (Coleoptera, Coccinellidae) in European Russia. - Ross. Zh. Biol. Inv. 2013: 75-82 [in Russian, English abstr.].

Osawa N. 1994: The occurrence of multiple mating in a wild population of the ladybird beetle Harmonia axyridis Pallas (Coleoptera: Coccinellidae). - J. Ethol. 12: 63-66.

PekIN V.P. 2007: Ecological and faunistical survey of coccinellids (Coleoptera, Coccinellidae) of the Urals and the south of Western Siberia. - Vest. Chelyab. Gosud. Univ. 2007(6): 95-107 [in Russian].

Poinar G.O. JR. \& SteEnberg T. 2012: Parasitylenchus bifurcatus n. sp. (Tylenchida: Allantonematidae) parasitizing Harmonia axyridis (Coleoptera: Coccinellidae). - Parasit. Vectors 5:218, 8 pp.

Prenter J., MacNeil C., Dick J.T.A. \& Dunn A.M. 2004: Roles of parasites in animal invasions. - Trends Ecol. Evol. 19: 385-390.

Rhule E.L., Majerus M.E.N., Jiggins F.M. \& Ware R.L. 2010: Potential role of the sexually transmitted mite Coccipolipus hippodamiae in controlling populations of the invasive ladybird Harmonia axyridis. - Biol. Contr. 53: 243-247.

RidDICK E.W. 2006: Influence of host gender on infection rate, density and distribution of the parasitic fungus, Hesperomyces virescens, on the multicolored Asian lady beetle, Harmonia axyridis. - J. Insect Sci. 6: 42, 15 pp.

RIDDICK E.W. 2010: Ectoparasitic mite and fungus on an invasive lady beetle: parasite coexistence and influence on host survival. - Bull. Insectol. 63: 13-20.

Riddick E.W. \& Cottrell T.E. 2010: Is the prevalence and intensity of the ectoparasitic fungus Hesperomyces virescens related to the abundance of entomophagous coccinellids? Bull. Insectol. 63: 71-78.

Riddick E.W. \& Schaefer P.W. 2005: Occurrence, density, and distribution of parasitic fungus Hesperomyces virescens (Laboulbeniales: Laboulbeniaceae) on multicolored Asian lady beetle (Coleoptera: Coccinellidae). - Ann. Entomol. Soc. Am. 98: 615-624.

Roy H.E., Lawson Handley L.-J., Schönrogge K., Poland R.L. \& PurSe B.V. 2011a: Can the enemy release hypothesis explain the success of invasive alien predators and parasitoids? - BioControl 56: 451-468.

Roy H.E., Rhule E., Harding S., Lawson Handley L.-J., RidDick E.W. \& SteEnBerg T. 2011b: Living with the enemy: parasites and pathogens of the ladybird Harmonia axyridis. - BioControl 56: 663-679.

Roy H.E., Adriaens T., Isaac N.J.B., Kenis M., Onkelinx T., San Martin G., Brown P.M.J., Hautier L., Poland R., Roy D.B., Comont R., Eschen R., Frost R., Zindel R., Van Vlaenderen J., Nedved O., Ravn H.P., Grégoire J.-C., de Biseau J.-C. \& MAES D. 2012: Invasive alien predator causes rapid declines of native European ladybirds. - Divers. Distrib. 18: 717-725.

SANTAMARIA S. 1989: El orden Laboulbeniales (Fungi, Ascomycotina) en la Península Ibérica e Islas Baleares. Edicions especials de la Societat Catalana de Micologia. Vol. 3. Esplugues, $396 \mathrm{pp}$.
Santamaria S., Balazuc J. \& Tavares I.I. 1991: Distribution of the European Laboulbeniales (Fungi, Ascomycotina). An Annotated List of Species. Treballs de l'Institut Botanic de Barcelona 14, $123 \mathrm{pp}$.

Sloggett J.J. 2012: Harmonia axyridis invasions: Deducing evolutionary causes and consequences. Entomol. Sci. 15: 261-273.

Steenberg T. \& Harding S. 2010: Entomopathogenic fungi found in field populations of the harlequin ladybird, Harmonia axyridis. - IOBC/WPRS Bull. 58: 137-141.

TAVARES I.I. 1979: The Laboulbeniales and their arthropod hosts. In Batra L.R. (ed.): Insect-Fungus Symbiosis, Nutrition, Mutualism, and Commensalism. Allanheld, Osmun \& Co., Montclair, pp. 229-258.

ThaXter R. 1891: Supplementary note on North American Laboulbeniaceae. - Proc. Am. Acad. Arts Sci. 25: 261-270.

ThaXter R. 1931: Contribution towards a monograph of the Laboulbeniaceae. Part V. - Mem. Am. Acad. Arts Sci. 16: $1-435$.

Tolasch T. 2002: Harmonia axyridis (Pallas, 1773) breitet sich in Hamburg aus - Ausgangpunkt für ein Besiedlung Mitteleuropas? - Entomol. Nachr. Ber. 46: 185-188.

Torchin M.E. \& Mitchell C.E. 2004: Parasites, pathogens, and invasions by plants and animals. Front. Ecol. Environ. 2: 183-190.

Tyumaseva Z.I. 1997: Results and goals of studies on coccinellids of the Urals. In Olschwang V., Bogacheva I., Nikolaeva N., Mikhailov Yu., Gorbunov P. \& Zinovjev E. (eds): Achievements on Entomology in the Urals. Russian Acad. Sci., Ural Branch, Ekaterinburg, pp. 63-66 [in Russian].

VERIZHNIKOVA I.V. 2011: Invasion by Harmonia axyridis (Coleoptera: Coccinellidae): population growth in Kyiv region. - Bull. Kharkiv Nat. Agr. Univ. (Phytopathol. Entomol.) 2011(9): 23-26 [in Ukrainian, English abstr.].

Wang S., Michaud J.P., Tan X.L., Zhang F. \& Guo X.J. 2011: The aggregation behavior of Harmonia axyridis in its native range in Northeast China. - BioControl 56: 193-206.

WebBerLey K.M. \& Hurst G.D.D. 2002: The effect of aggregative overwintering on an insect sexually transmitted parasite system. - J. Parasitol. 88: 707-712.

Webberley K.M., Hurst G.D.D., Husband R.W., Schulenburg J.H.G.V.D., Sloggett J.J., Isham V., Buszko J. \& Majerus M.E.N. 2004: Host reproduction and a sexually transmitted disease: causes and consequences of Coccipolipus hippodamiae distribution on coccinellid beetles. - J. Anim. Ecol. 73: $1-10$.

Webberley K.M., Tinsley M.C., Sloggett J.J., Majerus M.E.N $\&$ HURST G.D.D. 2006: Spatial variation in the incidence of a sexually transmitted parasite of the ladybird beetle Adalia bipunctata (Coleoptera: Coccinellidae). - Eur. J. Entomol. 103: 793-797.

WeIR A. \& BeAKEs G.W. 1996: Correlative light and scanning electron microscope studies on the developmental morphology of Hesperomyces virescens. - Mycologia 88: 677-693.

WeIR A. \& HAmmond P.M. 1997: Laboulbeniales on beetles: host utilization patterns and species richness of the parasites. - Biodivers. Conserv. 6: 701-719.

Welch V.L., Sloggett J.J., Webberley K.M. \& Hurst G.D.D. 2001: Short-range clinal variation in the prevalence of a sexually transmitted fungus associated with urbanisation. - Ecol. Entomol. 26: 547-550.

Received February 1, 2013; revised and accepted April 24, 2013 